\title{
Population Structure of Lutjanus purpureus (Lutjanidae - Perciformes) on the Brazilian coast: further existence evidence of a single species of red snapper in the western Atlantic
}

\author{
GRAZIELLE GOMES $^{1,2}$ IRACILDA SAMPAIO $^{1}$ and HORACIO SCHNEIDER ${ }^{1}$ \\ ${ }^{1}$ Laboratório de Genética e Biologia Molecular, Instituto de Estudos Costeiros, Universidade Federal do Pará, \\ Campus Universitário de Bragança, Alameda Leandro Ribeiro, s/n, 68600-000 Bragança, PA, Brasil \\ ${ }^{2}$ Laboratório de Genética Aplicada, Instituto de Estudos Costeiros, Universidade Federal do Pará, \\ Campus Universitário de Bragança, Alameda Leandro Ribeiro, s/n, 68600-000 Bragança, PA, Brasil
}

Manuscript received on November 10, 2010; accepted for publication on September 5, 2011

\begin{abstract}
The present study focus on the mitochondrial control region to investigate phylogeographic patterns and population structure in Lutjanus purpureus, and to evaluate the genetic similarity between L. purpureus and L. campechanus. For the initial analysis, 810 base pairs sequence from control region were obtained from 239 specimens of $L$. purpureus collected from four localities off the Brazilian coast. The results revealed the presence of a single panmictic population characterized by high values of genetic diversity. The 299 base pairs hypervariable portion were used for the combined analysis of $L$. purpureus and L. campechanus, being 275 haplotypes identified in the 414 specimens. Phylogenetic tree and haplotype network did not indicate phylogeographic substructuring between the two species, but rather an intense intermingling of individuals. Considering their marked morphological similarity, the molecular data presented here indicate that only one species of red snapper exists in the western Atlantic.
\end{abstract}

Key words: control region, Lutjanus purpureus.

\section{INTRODUCTION}

The family Lutjanidae includes four subfamilies Etelinae, Apsilinae, Paradichthyinae and Lutjaninae - that together encompass 107 species (Iwatsuki et al. 1993, Nelson 2006, Moura and Lindeman 2007), 20 of which are found in the western Atlantic (Allen 1985, Cervigón 1993). Most snapper species are commercially important fishery resources, exploited in a predatory fashion on either an industrial or an artisanal scale, as in the case of the red snapper, Lutjanus purpureus (Poey 1867), known in Brazil

Correspondence to: Iracilda Sampaio

E-mail:ira@ufpa.br as the pargo or vermelho. According to Cervigón (1993) and Allen (1985), this species is distributed throughout the Caribbean, south of Cuba, and Brazil - from northeast as far south as the state of Bahia. However, some authors such as Carpenter and Nelson (1971) and Rivas (1966) argue that the species can be found in some parts off the coast of the United States. The species is found primarily at depths of between 30 and 160 meters in areas with a sandy or rocky bottom (Paiva 1997), but is especially common at 70-120 m (Allen 1985). The adults are normally either solitary or found in small groups, whereas the juveniles congregate 
in large shoals (Szpilman 2000). Long-lived, but slow-growing (R.F.C. Souza, unpublished data) the largest individuals of this species may reach a total length of $100 \mathrm{~cm}$, although most adult fish are around $65 \mathrm{~cm}$ (Allen 1985).

Off the northern and eastern coast of Brazil, the species is catched mainly on the continental shelf and oceanic reefs (Ivo and Hanson 1982). Industrial harvesting began in Brazil in the $60 \mathrm{~s}$, and concentrated on the oceanic reefs off the northeastern coast (Fonteles-Filho 1972). Subsequently, the focus shifted to the continental platform, from the state of Ceará westwards to the Amazon coast of the states of Amapá, Pará, and Maranhão (Ivo and Sousa 1988, Paiva 1997). In the present day, the species is harvested mainly off Amapá and Pará.

Given the implications of such processes for the maintenance of stocks, there is growing interest in the genetic structure of the populations of commercially important fish species (Garber et al. 2004, Palstra et al. 2007, Santa Brígida et al. 2007, Rodrigues et al. 2008, Silva-Oliveira et al. 2008). These and other studies have generated an essential database for the development of systematic management strategies for fish stocks. The data also permit the analysis of evolutionary processes and past demographic events (Frankham et al. 2004). Studies of this kind usually focus on the mitochondrial control region and microsatellite markers, highly variable repeated sequences found in the nuclear genome.

Very little is known about the population structure of the red snappers of the western Atlantic, especially regarding molecular markers. However, Salles et al. (2006) conducted a pioneering study using a molecular tool (the mitochondrial cytochrome $\mathrm{b}$ gene, together with morphological variables) for the analysis of the structure of the red snapper populations off the northern coast of Brazil. The results of this study indicated the presence of two distinct stocks of L. purpureus on the northern coast of Brazil associated with different fishery zones. Four haplotypes were identified, two of which were associated with the western zone $\left(47^{\circ}-49^{\circ} \mathrm{W}\right)$, coinciding with the mouth of the Amazon, and two with the eastern zone $\left(43^{\circ}-46^{\circ} \mathrm{W}\right)$. A similar division was identified in the morphometric study of SousaJúnior et al. (2002), suggesting a fragmentation degree of the populations in this region, based on its vast area and environmental heterogeneity.

In their analysis of biological characteristics, oceanographic conditions, and the evolution of fishing practices, Ivo and Hanson (1982) formulated two hypotheses to define the Brazilian stocks of red snapper and their migratory patterns. Their first step was to divide the region into four zones, two of which are mentioned above. These zones (III and IV) are associated with the Amazon estuary, and characterized by an extensive continental shelf, and relatively low salinity levels. By contrast, zones I and II refer to the Caiçara and Ceará oceanic reefs, which are separated from the continental shelf by deep depressions. These areas are characterized by high salinity, and a predominance of calcareous algae on the ocean floor.

One hypothesis presented by Ivo and Hanson (1982) is that only a single stock of Brazilian red snappers exists. This stock is composed of individuals originating from distinct breeding seasons. The alternative to this would be the presence of two stocks, resulting from geographically distinct breeding populations. In both cases, the adults migrate between feeding areas on the continental shelf (zones III and IV), to breeding areas on the oceanic reefs (zones I and II). The eggs and larvae would be transported to nursery areas on the continental shelf by the Guianas current, the difference being that, in the case of the second hypothesis, each stock would migrate to breed at a different reef.

Recently, Gomes et al. (2008) analyzed northern Brazilian populations of $L$. purpureus based on sequences of the mitochondrial control region, and found evidence of intense gene flow between populations, indicating the presence of a 
single genetic stock. Furthermore, comparisons with a second snapper species, Lutjanus campechanus revealed greater variation within than between populations, indicating a lack of phylogeographic structuring, and the probable existence of only a single species of red snapper in the western Atlantic, as suggested by Cervigón (1993). These findings are supported by the marked morphological similarities of the two forms (Rivas 1966, Allen 1985, Moran 1988, Cervigón 1993), as well as their many shared characteristics, such as their longevity, slow maturation, and reproductive patterns (Moran 1988, Wilson and Nieland 2001, Souza et al. 2003, R.F.C. Souza, unpublished data). The existence of a single red snapper species in the western Atlantic would also be consistent with the situation observed in other Lutjanus species (Cervigón 1993).

In general, taxonomic uncertainties arise from a lack of data for analyses. The adequate definition of species is a decisive step in the evaluation of conservation status, and the development of effective management strategies (Frankham et al. 2004). In the present study, the mitochondrial control region was analyzed in order to evaluate the genetic structure and phylogeographic attributes of Brazilian populations of L. purpureus. In addition to the expansion of the analysis of Gomes et al. (2008), in terms of the number and distribution of samples, a complementary analysis of the hypervariable portion of the control region included the sequences obtained from western Atlantic $L$. campechanus by Garber et al. (2004).

\section{MATERIALS AND METHODS}

SAMPLES

The L. purpureus specimens analyzed in the present study were collected at four areas on the Brazilian coast (Fig. 1), two in northern coast of Brazil, one in Ceará and one in Bahia, providing a representative sample of the Brazilian distribution of the species (Allen 1985, Cervigón 1993). The samples from northern coast were obtained from local fishing ports, as well as the Northern Regional Center for Fishery Research and Development (CEPNOR frm Portuguese), as part of collaboration with the Universidade Federal Rural da Amazonia (UFRA). The samples from Ceará and Bahia were obtained from fishing companies in the cities of Fortaleza and Salvador, respectively. Only specimens with a reliable known origin were included in the study. All procedures were carried out according to the international practices for animal use and care under the control of an internal committee of the Universidade Federal do Pará, Brazil.

Morphological identification of the specimens was carried out in the field, and then tissue samples (muscle and/or tongue) were extracted and taken to the Genetics and Molecular Biology Laboratory of the Bragança Campus of the Universidade Federal do Pará (UFPA), where they were stored in the Lutjanidae tissue bank.

In order to test the genetic differentiation hypothesis proposed by Sousa-Júnior et al. (2002) and Salles et al. (2006), the samples from northern coast of Brazil (CNB) were divided into two groups, CNB I and CNB II, according to a longitudinal gradient. Group I included all the specimens captured between longitudes $46^{\circ}$ and $50^{\circ} \mathrm{W}$, while Group II included the individuals taken between $43^{\circ} \mathrm{W}$ and $45^{\circ} \mathrm{W}$. This subdivision follows the red snapper fishery zoning scheme of Ivo and Hanson (1982), in which "subarea IV" corresponds to CNB I, and "subarea III" to CNB II.

A total of 239 specimens of L. purpureus were collected for the present study, 119 of which from area CNB I, 49 from CNB II, 43 from Ceará, and 28 from Bahia. An additional 175 sequences of the congener L. campechanus were obtained from the literature (Garber et al. 2004). These specimens were collected in the western Atlantic and the Gulf of Mexido, and include six individuals from Alabama, 13 from Cancún (Mexico), six from Louisiana, 115 from Mississippi, and 35 from the Atlantic coast of Florida (Fig. 1). 


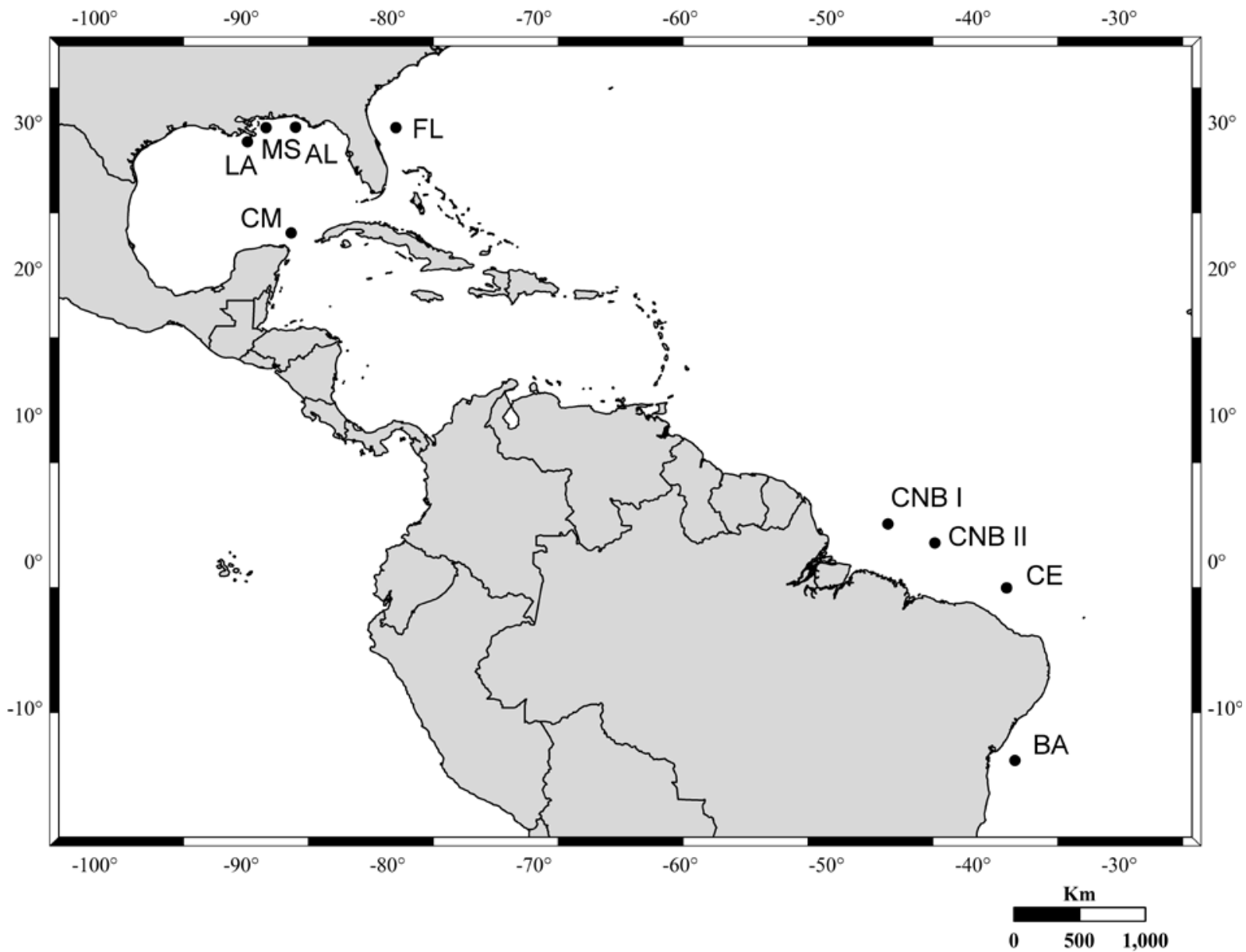

Fig. 1 - Locations of the areas in which the specimens of L. purpureus (Brazil) and L. campechanus (United States and Mexico: Garber et al. 2004) were collected. LA: Louisiana; MS: Mississippi; AL: Alabama; FL: Florida; CM: Cancun, México; CNB: northern coast of Brazil (CNB I - Longitudes: $46^{\circ}$ and $50^{\circ} \mathrm{W}$; CNB II - Longitudes: $43^{\circ}$ and $45^{\circ} \mathrm{W}$ ); CE: Ceará; BA: Bahia.

EXTRACTION OF DNA, AMPLIFICATION AND SEQUENCING OF THE MitochONDRIAL CONTROL REGION

Isolation of the genomic DNA was carried out using the technique developed by Sambrook and Russel (2001), which involves digesting enzymes (RNase, Proteinase K), phenol, chloroform, and isoamyl alcohol for the precipitation of the proteins, andalcohol (isopropanol and ethanol) for the precipitation of the DNA. The mitochondrial control region was isolated and amplified using the Polymerase Chain Reaction (PCR) technique, using the primers Dloop-A-5'TTCCACCTCTAACTCCCAAAGCTAG-3' and Dloop-G-5'-CGTCGGATCCCATCTTCAGTGT
TATGCTT-3 (Lee et al. 1995), which are located on the transfer RNA (tRNAs) that flank the control region, the proline and phenylalanine tRNAs, respectively. Additionally, the primers Dloop-F-5'ACTTTCATCGACGCTTGCA-3' and Dloop-R5'GTGATCTTAGGAGTATAGGG-3' were used to isolate the hypervariable region described by Garber et al. (2004), and thus permitting the analysis of practically the whole control region. Figure 2 shows the location of the hypervariable region sequenced by Garber et al. (2004), and the fragments sequenced by Gomes et al. (2008) and in the present study.

The PCRs were conducted in a final volume of $25 \mu \mathrm{L}$, which included: $4 \mu \mathrm{L}$ of the mixture of 
deoxynucleotides $(1.25 \mathrm{mM}), 2.5 \mu \mathrm{L}$ of the $\mathrm{Taq}$ enzyme buffer $(10 \mathrm{x}), 0.75 \mu \mathrm{L}$ of $\mathrm{MgCl}_{2}(50 \mathrm{mM})$, approximately $100 \mathrm{ng}$ of the total DNA extracted from the sample, $0.25 \mu \mathrm{L}$ of each primer $(200 \mathrm{ng} / \mu \mathrm{L}), 0.2$ $\mu \mathrm{L}$ of Taq DNA polymerase ( $5 \mathrm{U} / \mu \mathrm{L}$ - Invitrogen) and sterile distilled water to complete the final reaction volume. The amplification protocol was as follows: initial denaturation for 3 minutes at $94^{\circ} \mathrm{C}$, followed by 35 cycles of 30 seconds at $94^{\circ} \mathrm{C}$ (denaturation), 1 minute at $57^{\circ} \mathrm{C}$ (hybridization) and 2 minutes at $72^{\circ} \mathrm{C}$ (extension). At the end of the 35 cycles, there was a final extension of 7 minutes at $72^{\circ} \mathrm{C}$.

The amplicons were purified using the ExoSAP-IT kit (Amersham Pharmacia Biotech Inc., UK) according to the maker's instructions. Once purified, the samples were sequenced using the dideoxyterminal method of Sanger et al. (1977) with a Big Dye reagent kit (ABI Prism ${ }^{\mathrm{TM}}$ Dye Terminator Cycle Sequencing Reading Reaction).
The precipitated product was sequenced in an ABI 3100 automatic capillary sequencer (Applied Biosystems - Perkin Elmer). The primers used for the sequencing reaction were Dloop-A (Lee et al. 1995) and Dloop-F (Garber et al. 2004).

\section{SeQuence Edition And Alignment}

The sequence files and the electropherograms were transferred to a computer for alignment and edition, using BioEdit (Hall 1999). Once the nucleotides were conferred, the sequences containing errors or uncertainties were corrected. An automatic multiple alignment was then performed in the Clustal-X application (Thompson et al. 1997), followed by a new visual inspection and correction of the insertions or deletions codification as necessary. Two databases were produced, the first covering the $810 \mathrm{bp}$ of the mitochondrial control region identified in the Brazilian specimens of

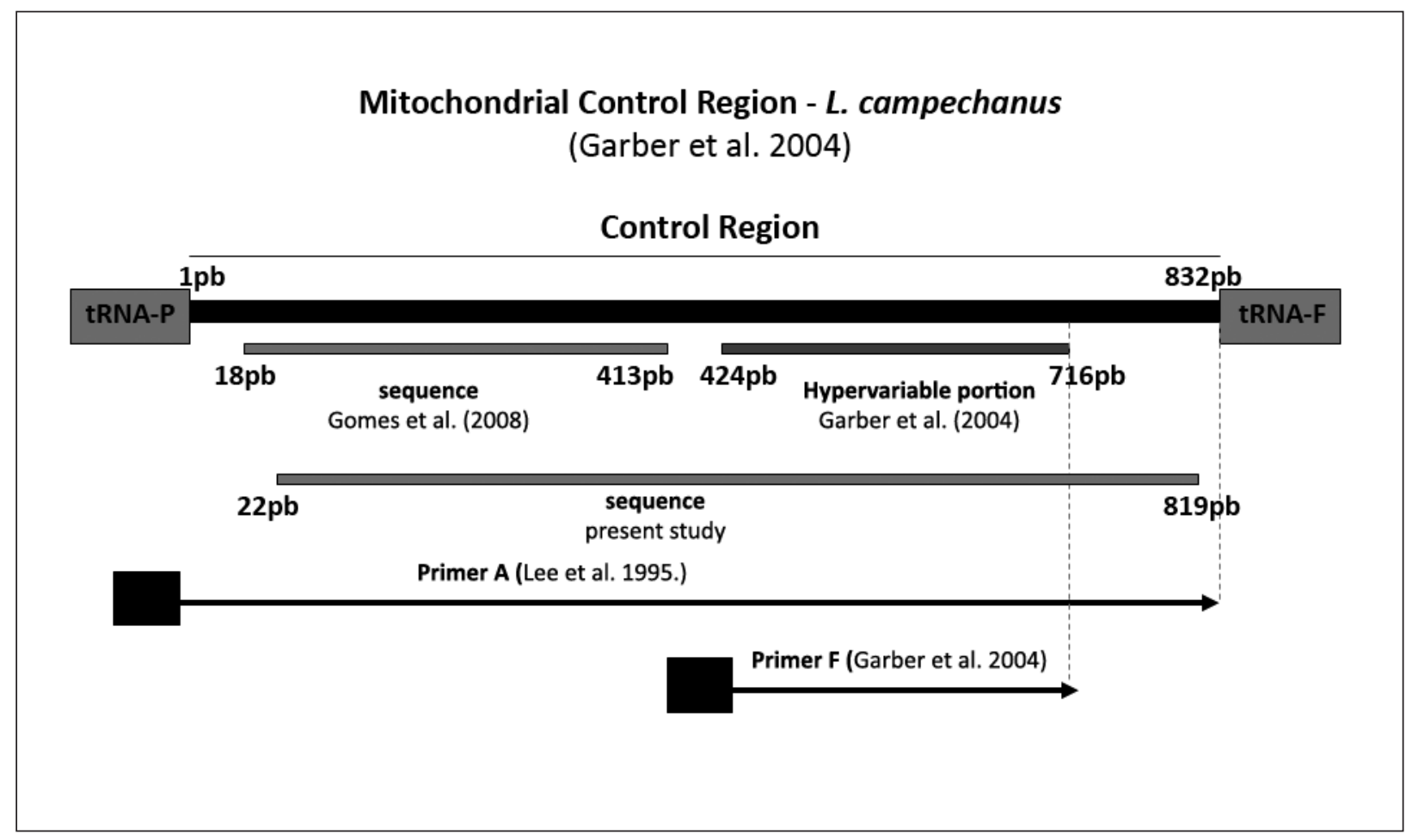

Fig. 2 - Schematic representation of the complete sequence of the mitochondrial control region in L. campechanus, showing the fragments sequenced by Gomes et al. (2008) and Garber et al. (2004), and the primers used in the present study. 
L. purpureus. The second set of data covered only the hypervariable portion of the control region - a sequence of 299 bp - including both $L$. purpureus and L. campechanus.

Saturation of the data was analyzed by DAMBE, version 4.2.13 (Xia and Xie 2001), which plotted mutation rates (transitions and transversions) as a function of the genetic divergence among the sequences.

Analysis of Phylogeographic Processes AND POPULATION GENETICS

The phylogenetic relationships among haplotypes were evaluated through neighbor-joining analyses using MEGA 4.0 (Tamura et al. 2007). The significance of the groupings in all generated trees were estimated using bootstrap analysis, based on 1,000 pseudo-replicates. The distance model used to construct the phylogenetic tree and the nucleotide divergence matrix considered the relative difference between sequences based on pairwise comparisons, the simplest evolutionary model, with no correction for superimposed mutations. The first analysis investigated the phylogenetic relationships of the control region haplotypes of Brazilian $L$. purpureus, while the second approach involved a smaller sequence - the hypervariable portion of the D-loop - but a wider range of samples, through the inclusion of L. campechanus. For both analyses specimens of Lutjanus synagris collected off the coast of Bahia were used as outgroup.

Additional parameters included the nucleotide composition, and the number of polymorphic and informative sites for parsimony analysis, determined by MEGA 4.0 (Tamura et al. 2007). The number of substitutions (transitions and transversions) was calculated using the Arlequin program (Excoffier et al. 2005). Within-population genetic diversity was evaluated based on the indices of haplotype (h) and nucleotide $(\pi)$ diversity (Nei 1987 ) provided by the programs DnaSP v 5 (Librado and Rozas 2009) and Arlequin 3.01 (Excoffier et al. 2005). An Analysis of Molecular Variance, AMOVA (Excoffier et al.
1992), based on 20,000 permutations was used to evaluate the proportion of genetic variation within and between $L$. purpureus populations, and between this species and L. campechanus. The latter analysis was used to look for the possible existence of distinct genetic stocks in the southwestern (Brazil) and northwestern (USA and Mexico) Atlantic.

Genetic differentiation between pairs of populations was evaluated using the Fixation index, $F_{\mathrm{ST}}$ (Weir and Hill 2002), the significance of which was determined using 20,000 permutations, as well as using $F / \Phi_{\mathrm{ST}}$ of AMOVA. The haplotype network was constructed using the median vector method available in the NETWORK 4.5 program (Bandelt et al. 1999).

\section{DEMOGRAPHIC HISTORY AND NEUTRALITY}

The mismatch distribution (number of observed differences between pairs of haplotypes) was used to evaluate the demographic history of the populations of L. purpureus and L. campechanus. This analysis permits the identification of populations that were stable, expanding, or have passed through bottlenecks in the past (Frankham et al. 2004). When the pairwise differences were plotted on a graph, a unimodal distribution indicates a sudden explosive demographic expansion (Slatkin and Hudson 1991, Rogers and Harpending 1992), whereas stable populations will present an irregular profile due to either the stochastic loss of lineages (Slatkin and Hudson 1991, Aris-Brosou and Excoffier 1996) or secondary contact among populations following a long period of isolation (Frankham et al. 2004). By contrast, populations that have passed through severe bottlenecks with a drastic reduction in genetic variation have either a bimodal or a null distribution, depending on whether the bottleneck only reduced genetic diversity, or eliminated it altogether (Frankham et al. 2004).

The analyses of the mismatch distribution were carried out in Arlequin 3.01 (Excoffier et al. 2005), with the graph being generated in Microsoft 
Excel. The mutation parameters before $\left(\theta_{0}=2 N_{0} u\right)$ and after $\left(\theta_{l}=2 N_{l} u\right)$ expansion were determined using Schneider and Excoffier's (1999) least-square approach, using $\tau$ as the estimator of expansion time. The equation $\tau=2 u t$ (Rogers and Harpending 1992) was used to estimate the probable expansion time of the populations, where $u=2 \mu_{0} \mathrm{~K}$ (K = number of nucleotides and $\mu_{0}=$ mutation rate of the genomic region). A mutation rate of $10-13 \%$ per million years was used here as the evolutionary rate of the mitochondrial control region in fish (Brown et al. 1993, Zhang et al. 2006), while generation time was set at five years, which corresponds to the age at which female L. purpureus reach sexual maturity ( R.F.C. Souza, unpublished data, Souza et al. 2003). In addition, the raggedness index (Harpending 1994) and the sum of the squared deviations (SSD) between observed and expected mismatch distributions were calculated. These analyses were also run in Arlequin 3.01 (Excoffier et al. 2005), and were used to validate the estimated expansion model (Schneider and Excoffier 1999). Significance was estimated using a parametric bootstrap analysis.

Fu's (Fs) and Tajima's (D) neutrality tests (Tajima 1989, Fu 1997) were run based on 20,000 simulations, in Arlequin 3.01. Values of both $D$ and $F s$ were negative when there were an excess of recent mutations, which may indicate recent population expansion, or other evolutionary processes, such as a hitchhiker effect or natural selection (Fu 1997). Positive values may indicate balancing selection, population subdivision or bottlenecks (Tajima 1989).

\section{RESULTS}

Phylogeography And Population StRUCTURE IN L. PURPUREUS

A total of 810 base pairs (bp) were obtained from the control region of the 239 Brazilian specimens of L. purpureus (Fig. 1). Mean nucleotide composition was $30.34 \%$ for Thymine, $21.33 \%$ for Cytosine,
$32.32 \%$ for Adenine, and $16.01 \%$ for Guanine. Just over a third of the sites (274) were polymorphic, while 527 were conserved. Of the variable sites, 181 were informative for parsimony analysis, while 93 were singletons. A total of 299 substitutions were observed, of which, 260 were transitions, and 39 transversions. The plot of transition/transversion rates vs. genetic distance (not shown) did not indicate the presence of saturation.

No less than 220 haplotypes were detected in the 239 specimens, indicating very high levels of haplotype diversity. The most common haplotype (72) was shared by only five individuals, but was recorded in three populations (CNB I, CNB II and Bahia). No haplotype was recorded in all four populations. In fact, only 13 haplotypes were present in more than one individual, which means that $94.1 \%$ of haplotypes were unique, although most were distinguished by a small number of mutations. This situation was also reflected in the predominance $(95.5 \%)$ of exclusive haplotypes in the four populations. Genetic distances between $L$. purpureus haplotypes varied from $0.1 \%$ to $6.1 \%$, while those with the outgroup (L. synagris) ranged from $9.8 \%$ to $12.3 \%$. The most divergent haplotype (207) was recorded in the Bahia population, and diverged by more than $3.5 \%$ in all comparisons. The red snapper populations present considerable genetic variability, considering either the haplotype or nucleotide indices (Table IA). Spatially, the eastern populations (Bahia and Ceará) were relatively more polymorphic, with mean nucleotide diversity of $2.8 \%$, despite their much smaller samples.

In order to test the hypothesis that Brazilian red snappers were divided into distinct genetic stocks, three different approaches were applied for the AMOVA. In the first analysis, the western (CNB I and CNB II) and eastern (Ceará and Bahia) populations were grouped together. Subsequently, the populations CNB and Ceará were separated from that of the eastern coast (Bahia). The third approach involved the allocation of all four populations into 
TABLE I

Sample size, number of haplotypes and indices of nucleotide and haplotype diversity for: (A) the mitochondrial control region in Brazilian L. purpureus, and (B) the hypervariable portion of the control region in Brazilian $L$. purpureus (present study) and L. campechanus sampled by Garber et al. (2004).

\begin{tabular}{|c|c|c|c|c|}
\hline Population & $\mathbf{N}$ & $\begin{array}{l}\text { Number of } \\
\text { haplotypes }\end{array}$ & $\begin{array}{l}\text { Haplotype diversity } \\
(\mathbf{h} \pm \mathbf{s d})\end{array}$ & $\begin{array}{l}\text { Nucleotide diversity } \\
(\chi \pm \mathbf{s d})\end{array}$ \\
\hline \multicolumn{5}{|c|}{ (A) Mitochondrial control region L. purpureus } \\
\hline Costa Norte Brasil (CNB I) & 119 & 113 & $0.999 \pm 0.001$ & $0.026 \pm 0.013$ \\
\hline Costa Norte Brasil (CNB II) & 49 & 49 & $1.000 \pm 0.004$ & $0.025 \pm 0.012$ \\
\hline Ceará (CE) & 43 & 43 & $1.000 \pm 0.005$ & $0.028 \pm 0.014$ \\
\hline Bahia (BA) & 28 & 26 & $0.994 \pm 0.011$ & $0.028 \pm 0.014$ \\
\hline Total & 239 & 220 & $0.999 \pm 0.0006$ & $0.026 \pm 0.013$ \\
\hline \multicolumn{5}{|c|}{ (B) Hypervariable portion L. purpureus } \\
\hline Costa Norte Brasil (CNB I) & 119 & 95 & $0.994 \pm 0.002$ & $0.031 \pm 0.016$ \\
\hline Costa Norte Brasil (CNB II) & 49 & 43 & $0.992 \pm 0.006$ & $0.029 \pm 0.015$ \\
\hline Ceará (CE) & 43 & 42 & $0.998 \pm 0.005$ & $0.033 \pm 0.017$ \\
\hline Bahia (BA) & 28 & 25 & $0.992 \pm 0.011$ & $0.033 \pm 0.017$ \\
\hline Total & 239 & 173 & $0.995 \pm 0.001$ & $0.031 \pm 0.016$ \\
\hline \multicolumn{5}{|l|}{ L. campechanus } \\
\hline Alabama (AL) & 06 & 06 & $1.000 \pm 0.096$ & $0.026 \pm 0.016$ \\
\hline Cancún (CM) & 13 & 11 & $0.961 \pm 0.049$ & $0.017 \pm 0.010$ \\
\hline Louisiana (LA) & 06 & 06 & $1.000 \pm 0.096$ & $0.019 \pm 0.012$ \\
\hline Mississippi (MS and FH-1) & 115 & 80 & $0.948 \pm 0.017$ & $0.020 \pm 0.010$ \\
\hline Florida $(\mathrm{FL})$ & 35 & 25 & $0.936 \pm 0.034$ & $0.025 \pm 0.013$ \\
\hline Total & 175 & 109 & $0.946 \pm 0.014$ & $0.020 \pm 0.010$ \\
\hline Total Lutjanus & 414 & 275 & $0.985 \pm 0.003$ & $0.028 \pm 0.000$ \\
\hline
\end{tabular}

a single group. In all three approaches, the majority of the variation was found within populations, rather than between populations or groups (Table IIA). Furthermore, the values of $F_{s t}$ and $F / \Phi_{\text {st }}$ considering both the pairwise comparisons and AMOVA, respectively, were low or negative and not significant, indicating intense gene flow among populations. These results point clearly to the existence of a single panmictic population of red snapper in Brazilian waters, extending all along the northern coast and as far south as Bahia. The panmixia of this population was also supported by the phylogenetic tree (due to the large number of haplotypes, the figure is not shown here), in which individuals from different localities were mixed together in a single clade, completely lacking any phylogeographic structuring. The star-shaped haplotype network (Fig. 3A) further supports the existence of a single genetic stock of Brazilian L. purpureus.

The plots of the pairwise differences between haplotypes were almost invariably unimodal, for both individual populations and the sample as a whole, which suggests a process of population expansion (Fig. 4A). The only exception was the population from Bahia, which presented an irregular profile, probably the result of the relatively small size of the sample from this locality. In addition, the values of $F s$ (Fu 1997) were significantly negative 
TABLE II

Analysis of Molecular Variance (AMOVA) for: (A) Brazilian L. purpureus (810 bps of the mitochondrial control region); (B) western Atlantic L. purpureus and L. campechanus (hypervariable portion of the control region). Populations: CBN: Northern Brazilian Coast; CE: Ceará; BA: Bahia; RMS: Mississippi; AL: Alabama; LA: Louisiana; FL: Florida; CM: Cancun, Mexico. Significance level: ns: not significant; $*=P<0.05 ; * *=P<0.01$.

\begin{tabular}{|c|c|c|c|}
\hline Groupings & Variance & $\%$ variation & $\mathbf{F} / \boldsymbol{\Phi}$ \\
\hline \multicolumn{4}{|c|}{ (A) L. purpureus CNB I, II vs. CE, BA } \\
\hline Between groups & $-0.07430 \mathrm{Va}$ & -0.69 & $\mathrm{~F} / \boldsymbol{\Phi}_{\mathrm{CT}}=-0.00688^{\mathrm{ns}}$ \\
\hline Between populations & $0.06918 \mathrm{Vb}$ & 0.64 & $\mathrm{~F} / \boldsymbol{\Phi}_{\mathrm{SC}}=0.00636^{\mathrm{ns}}$ \\
\hline Within populations & $10.80960 \mathrm{Vc}$ & 100.05 & $\mathrm{~F} / \boldsymbol{\Phi}_{\mathrm{ST}}=-0.00047^{\mathrm{ns}}$ \\
\hline \multicolumn{4}{|c|}{ CNB I, II + Ceará vs. Bahia } \\
\hline Between groups & $0.05781 \mathrm{Va}$ & 0.53 & $\mathrm{~F} / \boldsymbol{\Phi}_{\mathrm{CT}}=0.00533^{\mathrm{ns}}$ \\
\hline Between populations & $-0.05133 \mathrm{Vb}$ & -0.47 & $\mathrm{~F} / \boldsymbol{\Phi}_{\mathrm{SC}}=-0.00476^{\mathrm{ns}}$ \\
\hline Within populations & $10.83626 \mathrm{Vc}$ & 99.94 & $\mathrm{~F} / \boldsymbol{\Phi}_{\mathrm{ST}}=0.00060^{\mathrm{ns}}$ \\
\hline \multicolumn{4}{|l|}{ All populations } \\
\hline Between populations & $0.02245 \mathrm{Va}$ & 0.21 & $\mathrm{~F} / \boldsymbol{\Phi}_{\mathrm{ST}}=0.00207^{\mathrm{ns}}$ \\
\hline Within populations & $10.80960 \mathrm{Vb}$ & 99.79 & \\
\hline \multicolumn{4}{|c|}{$\begin{array}{l}\text { (B) L. purpureus and L. campechanus } \\
\text { (RMS, AL, LA) vs. (FL, CM) vs. (CNB I, II) vs. (CE, BA) }\end{array}$} \\
\hline Between groups & $0.84621 \mathrm{Va}$ & 17.35 & $\mathrm{~F} / \mathbf{\Phi}_{\mathrm{CT}}=0.173 *$ \\
\hline Between populations & $0.01416 \mathrm{Vb}$ & 0.29 & $\mathrm{~F} / \boldsymbol{\Phi}_{\mathrm{SC}}=0.003^{\mathrm{ns}}$ \\
\hline Within populations & $4.01677 \mathrm{Vc}$ & 82.36 & $\mathrm{~F} / \boldsymbol{\Phi}_{\mathrm{ST}}=0.176^{* *}$ \\
\hline \multicolumn{4}{|c|}{ Northern Atlantic vs. Southern Atlantic } \\
\hline Between groups & $1.24372 \mathrm{Va}$ & 23.67 & $\mathrm{~F} / \boldsymbol{\Phi}_{\mathrm{CT}}=0.236^{* *}$ \\
\hline Between populations & $-0.00583 \mathrm{Vb}$ & -0.11 & $\mathrm{~F} / \boldsymbol{\Phi}_{\mathrm{SC}}=-0.001^{\mathrm{ns}}$ \\
\hline Within populations & $4.01677 \mathrm{Vc}$ & 76.44 & $\mathrm{~F} / \boldsymbol{\Phi}_{\mathrm{ST}}=0.236^{* *}$ \\
\hline \multicolumn{4}{|l|}{ All populations } \\
\hline Between populations & $0.75075 \mathrm{Va}$ & 15.75 & $\mathrm{~F} / \boldsymbol{\Phi}_{\mathrm{ST}}=0.157 * *$ \\
\hline Within populations & $4.01677 \mathrm{Vb}$ & 84.25 & \\
\hline
\end{tabular}

for all populations, which indicates the non-neutral nature of the marker used here, and supports the hypothesis of demographic expansion. The values of $D$ (Tajima 1989) were all negative, although they were only significant for the two western (CNB) populations and the sample as a whole (Table IIIA). These results also support the idea that the Brazilian red snapper population is undergoing expansion, as well as indicating the occurrence of recent mutations and haplotypes with very low frequencies. These conclusions are also supported by the SSD and raggedness index (Harpending 1994). Given the mutation rate selected (10-13\% per million years), the values of $\mu$ vary from $5.0 \times 10^{-8}$ to $6.5 \times 10^{-8}$, and considering the 810 bps sequenced here and a generation of five years, values of $u$ ranged from $20,250 \times 10^{-8}$ to $26,325 \times 10^{-8}$. The estimated value of $\tau$ was 23,162 , which indicates that the expansion of the Brazilian population of red snappers took place approximately at 220,000 to 286,000 years ago. 

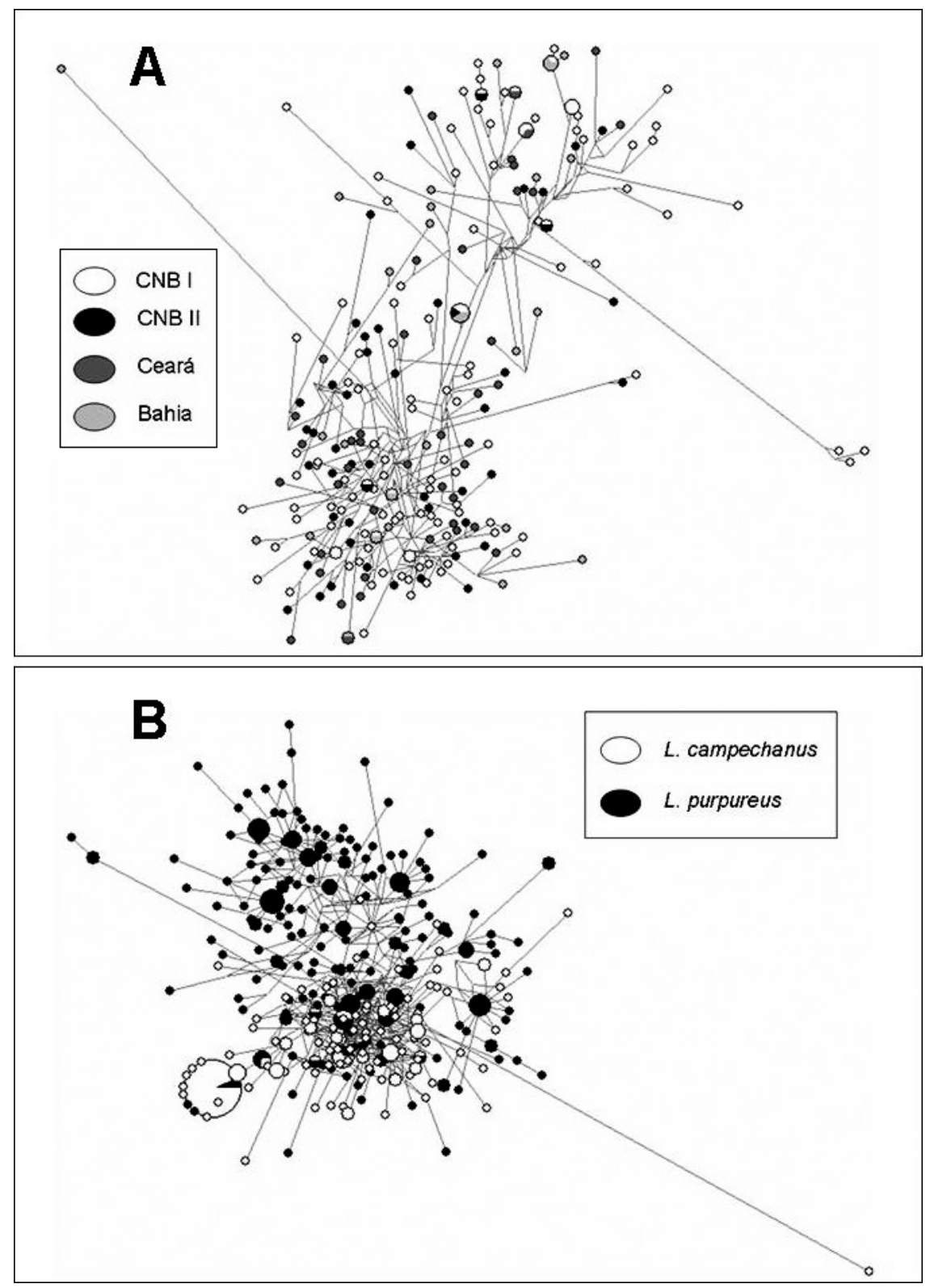

Fig. 3 - Haplotype networks based on (A) the mitochondrial control region (810 bps) of Brazilian $L$. purpureus, and (B) the hypervariable portion of the control region in L. purpureus and L. campechanus.

\section{PURPUREUS AND L. CAMPECHANUS: ONE OR TWO SPECIES?}

The $299 \mathrm{bp}$ sequence corresponding to the hypervariable portion of the control region was analyzed in 414 individuals representing L. purpureus $(\mathrm{n}=239)$ and L. campechanus ( $\mathrm{n}=175$ ) from a range of localities (Fig. 1). The $L$. campechanus sequences (Garber et al. 2004) were obtained from GenBank (access codes: AF356881-
7004; AF356750-776; AY153500-23). The hypervariable region described by Garber et al. (2004) was located in the second half of the control region, roughly between nucleotides 420 and 720 (Fig. 2).

The mean overall nucleotide composition (considering all 414 specimens) was $32.2 \%$ for Thymine, $20.8 \%$ for Cytosine, $26.3 \%$ for Adenine, and $20.7 \%$ for Guanine. As for the control region 


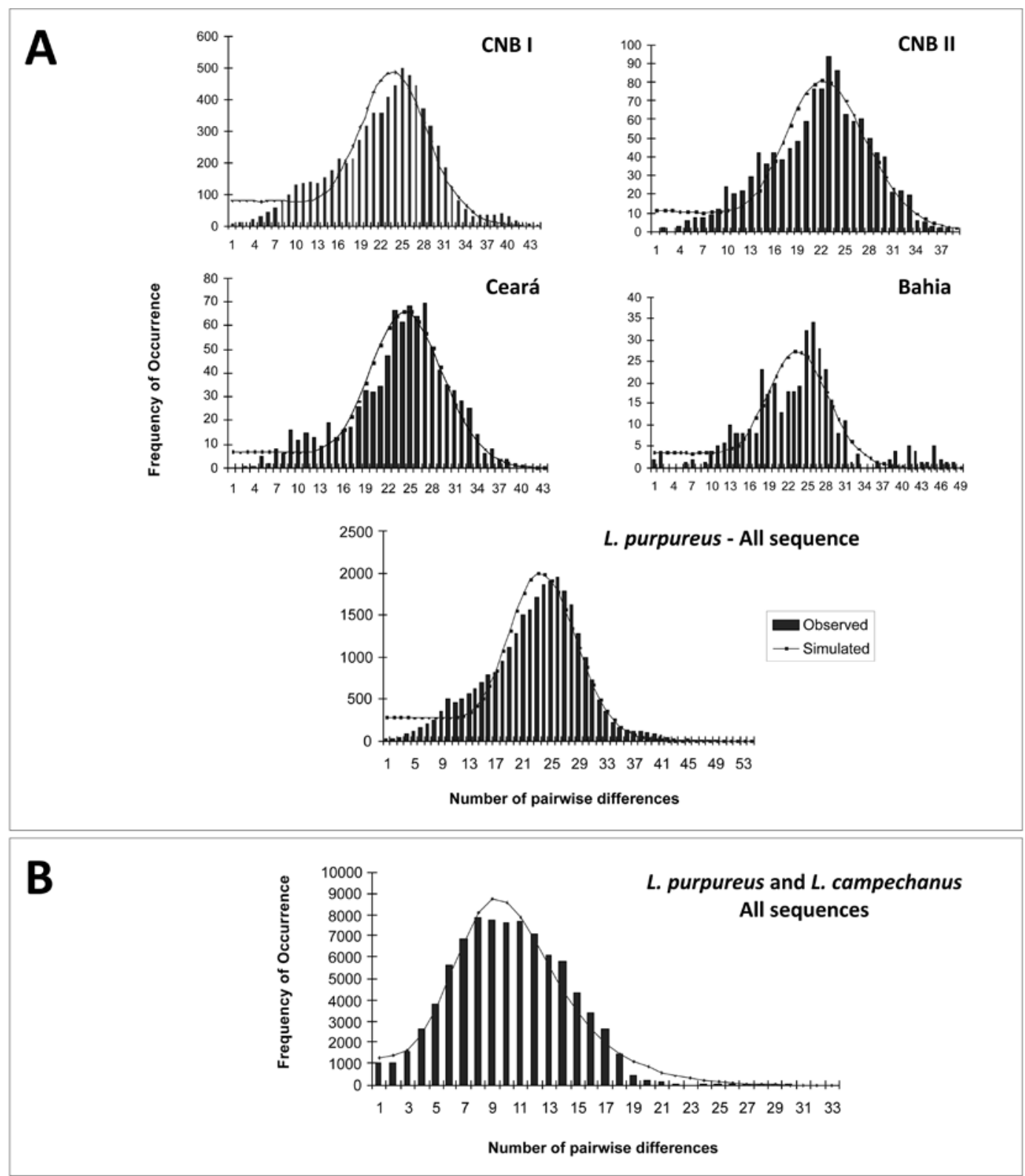

Fig. 4 - Distribution of pairwise differences between haplotypes based on sequences of the mitochondrial control region in: (A) L. purpureus from four Brazilian localities (CNBI, CNB II, Ceará, and Bahia) and all sequences, and (B) L. purpureus and L. campechanus ( $\mathrm{n}=414)$ from the western Atlantic.

as a whole, just over a third (101) of sites were polymorphic, while 195 were conserved. Sixtythree of the sites were informative for parsimony analysis, while 38 were singletons. There were 122 substitutions, 94 of which were transitions, and 28 transversions.

A total of 275 haplotypes were observed in the 414 specimens. When the sites containing deletions were omitted from the analysis, this total dropped to 240 , although the overall pattern of frequency and distribution was maintained. The most common haplotype (14) was shared by 43 individuals representing all populations except CNB II and Ceará, while it was most abundant in Mississippi and Florida. Others, such as haplotypes 1, 4, 6, and 17 , were found in three to seven individuals, 
TABLE III

Results of the analysis of the pairwise differences (mismatch) between the control region haplotypes of:

(A) Brazilian $L$. purpureus, and (B) western Atlantic $L$ campechanus and $L$. purpureus.

Significance level: ns: not significant; $*=P<0.05 ; * *=P<0.01$.

\begin{tabular}{|c|c|c|c|c|c|c|c|c|c|c|c|}
\hline Population & $N$ & $\tau$ & $\theta_{0}$ & $\theta_{1}$ & Variance & $S S D$ & $P$ & Raggedness & $P$ & Fs & $D$ \\
\hline \multicolumn{12}{|l|}{ (A) L. purpureus } \\
\hline CNB I & 119 & 23,971 & $\begin{array}{c}0.063 \\
(0,000-5,998)\end{array}$ & $\begin{array}{c}87,544 \\
(41,548- \\
99999,000)\end{array}$ & 50,557 & 0.0013 & 0.6950 & 0.0009 & 0.9980 & $-23.894 * *$ & $-1.544 *$ \\
\hline CNB II & 49 & 20,625 & $\begin{array}{c}2,215 \\
(0,000-12,052)\end{array}$ & $\begin{array}{c}106,948 \\
(52,573- \\
99999,000)\end{array}$ & 41,357 & 0.0017 & 0.7360 & 0.0018 & 0.9850 & $-24.157 * *$ & $-1.458^{*}$ \\
\hline Ceará & 43 & 24,785 & $\begin{array}{c}0.005 \\
(0,000-6,291)\end{array}$ & $\begin{array}{c}129,580 \\
(60,233- \\
99999,000)\end{array}$ & 45,012 & 0.0013 & 0.9090 & 0.0022 & 0.9730 & $-24.067 * *$ & $-1.332^{\mathrm{ns}}$ \\
\hline Bahia & 28 & 23,734 & $\begin{array}{c}0.077 \\
(0,000-6,253)\end{array}$ & $\begin{array}{c}106,147 \\
(48,171- \\
99999,000)\end{array}$ & 61,046 & 0.0058 & 0.4280 & 0.0066 & 0.6790 & $-7.360 *$ & $-1.396^{\mathrm{ns}}$ \\
\hline Total & 239 & 23,162 & $\begin{array}{c}0.775 \\
(0,000-5,955)\end{array}$ & $\begin{array}{c}96,714 \\
(54,292- \\
99999,000)\end{array}$ & 49,553 & 0.0010 & 0.6410 & 0.0008 & 0.9930 & $-23.630 * *$ & $-1.704 * *$ \\
\hline \multicolumn{12}{|c|}{ (B) L. purpureus and L. Campechanus } \\
\hline L. purpureus & 239 & 9,088 & $\begin{array}{c}1,092 \\
(0,000-5,486)\end{array}$ & $\begin{array}{c}69,453 \\
(30,547- \\
99999,000)\end{array}$ & 13,284 & 0.0005 & 0.7470 & 0.0029 & 0.9020 & $-24.189 * *$ & $-1.086^{\mathrm{ns}}$ \\
\hline L. campechanus & 175 & 6,742 & $\begin{array}{c}0.004 \\
(0,000-3,143)\end{array}$ & $\begin{array}{c}29,966 \\
(12,284- \\
99999,000)\end{array}$ & 13,195 & 0.0015 & 0.6830 & 0.0081 & 0.7230 & $-24.905 * *$ & $-1.434 *$ \\
\hline Total & 414 & 7,414 & $\begin{array}{c}2,858 \\
(0,000-13,897)\end{array}$ & $\begin{array}{c}65,566 \\
(23,496- \\
99999,000)\end{array}$ & 16,963 & 0.0009 & 0.5940 & 0.0022 & 0.9290 & $-23.997 * *$ & $-1.275^{\mathrm{ns}}$ \\
\hline
\end{tabular}

but overall, only seven haplotypes were shared by the two species, while the others were exclusive to either $L$. purpureus (approximately $60 \%$ of the total) or L. campechanus (37\%). However, most of these haplotypes were distinguished by a small number of mutations.

Genetic divergence between L. purpureus and L. campechanus haplotypes varied from $0.4 \%$ to $9.3 \%$ (average of $2,9 \%$ ), and the most divergent haplotype (272) was from Florida. Most haplotypes varied by less than $3 \%$, however, even when comparing species such as the value of $0.7 \%$ recorded between individuals of the Mississippi and western Brazilian populations. These results and their implications are very similar to those found above for the control region (810 bps) in Brazilian L. purpureus. Genetic variation were relatively high, whether considering either haplotype or nucleotide diversity. This variation was greatest in the Brazilian L. purpureus, in particular the eastern populations, in which nucleotide diversity values were above 3\%. Overall, however, the pattern of genetic diversity was similar in the two species (Table IB).

Once again, three different approaches were used for the AMOVA (Table IIB). The first was based on four main geographic groups - the western (CNB I and II) and eastern (Ceará and Bahia) Brazilian groups, a Gulf group (Alabama, Louisiana, and Mississippi), and a Caribbean group (Florida and Cancún). In the second analysis, the 
specimens were grouped by species, representing the northwestern (L. campechanus) and southwestern (L. purpureus) Atlantic. The final approach was to include all the specimens in a single group.

As for the previous analysis of the complete control region in L. purpureus, the majority of the variation recorded in all three approaches was found within, rather than between groups. However, a moderate, but significant process of differentiation was observed between the two species $\left(F / \Phi_{\mathrm{CT}}=0.236, P<0.01\right.$; see Table II $)$, with significant values of $F / \Phi_{\mathrm{ST}}\left(F / \Phi_{\mathrm{ST}}=0.176\right.$; 0.236, $P<0.01$; see Table II). The pairwise $F_{s t}$ comparisons reconfirmed panmixia in the Brazilian snappers, with low or negative (non significant) values between all populations. A similar situation was recorded for L. campechanus (Table IV). However, when comparisons were made between species, the $F_{s t}$ values were significant in all cases except Louisiana vs. Bahia, possibly because of the reduced sample sizes for these populations. These results suggest a moderate degree of differentiation between the two species, despite their considerable similarities and sharing of haplotypes.

As before, the phylogenetic tree (not presented here because of the large number of haplotypes) was characterized by a complete mixing of individuals from the two species, resulting in the formation of a single clade with countless polytomies and reduced statistical support. This confirmed the absence of any systematic phylogeographic structuring between L. purpureus and L. campechanus, which was further reinforced by the star-shaped haplotype network (Fig. 3B).

The plot of the pairwise differences between hapotypes for the whole sample $(\mathrm{n}=414)$ revealed a unimodal distribution characteristic of historical population expansion (Fig. 4B). This was confirmed by the values of $\tau, \theta 0$ and $\theta 1$, SSD and the raggedness index (Table IIIB). In addition, the $F S$ values were negative and significant for all the populations, rejecting the neutrality of the marker used here, and emphasizing the process of population expansion. The $D$ values were negative for all the populations, but were only significant for L. campechanus (Table IIIB).

Estimates of population expansion were based on the same criteria used above for L. purpureus. However, as the two species have different ages of maturation, the calculations were conducted using both values, i.e. 2 years for L. campechanus (Moran 1988) and 5 years for L. purpureus (R.F.C. Souza, unpublished data, Souza et al. 2003). Using the same mutation rate as before, values of $\mu$ vary

TABLE IV

Matrix of Fst values for pairwise comparisons between populations of $L$. purpureus and L. campechanus from the western Atlantic. Significance level: ns: not significant; * $=\boldsymbol{P}<0.05 ; * *=P<0.01$.

\begin{tabular}{|c|c|c|c|c|c|c|c|c|}
\hline & \multicolumn{4}{|c|}{ L. purpureus } & \multicolumn{4}{|c|}{ L. campechanus } \\
\hline & CNBI & CNBII & Ceará & Bahia & Mississippi & Alabama & Louisiana & Florida \\
\hline CNBII & $0.010^{\mathrm{ns}}$ & & & & & & & \\
\hline Ceará & $-0.004^{\mathrm{ns}}$ & $-0.007^{\mathrm{ns}}$ & & & & & & \\
\hline Bahia & $-0.001^{\mathrm{ns}}$ & $0.013^{\mathrm{ns}}$ & $0.001^{\mathrm{ns}}$ & & & & & \\
\hline Mississippi & $0.238 * *$ & $0.324 * *$ & $0.295 * *$ & $0.198 * *$ & & & & \\
\hline Alabama & $0.175 * *$ & $0.248^{* *}$ & $0.203 * *$ & $0.117^{*}$ & $0.039^{\mathrm{ns}}$ & & & \\
\hline Louisiana & $0.118^{* *}$ & $0.193 * *$ & $0.148^{* *}$ & $0.061^{\mathrm{ns}}$ & $-0.001^{\mathrm{ns}}$ & $-0.027^{\mathrm{ns}}$ & & \\
\hline Florida & $0.192 * *$ & $0.266^{* *}$ & $0.232 * *$ & $0.144 * *$ & $-0.003^{\mathrm{ns}}$ & $0.007^{\mathrm{ns}}$ & $-0.005^{\mathrm{ns}}$ & \\
\hline Cancun & $0.206^{* *}$ & $0.290 * *$ & $0.251^{* *}$ & $0.158 * *$ & $-0.023^{\mathrm{ns}}$ & $0.000^{\mathrm{ns}}$ & $-0.003^{\mathrm{ns}}$ & $-0.027^{\mathrm{ns}}$ \\
\hline
\end{tabular}


from $5.0 \times 10^{-8}$ to $6.5 \times 10^{-8}$. Considering a generation time of 5 years and the $299 \mathrm{bps}$ sequenced here, $\mathrm{u}$ ranged from $7,475.0 \times 10^{-8}$ to $9,717.5 \times 10^{-8}$. The value of $\tau$ was estimated to be 7,414 , indicating that population expansion took place between approximately 191,000 and 248,000 years ago. The same result was obtained when a generation time of 2 years was considered.

\section{DISCUSSION}

\section{BRAZILIAN L. PURPUREUS}

\section{Phylogeography and Population Structure}

The species L. purpureus represents an important fishery resource throughout its distribution in the western Atlantic, although little is known of the genetic structure of its populations, despite the value of such knowledge for the management of stocks. The results of the present study reconfirm the findings of Gomes et al. (2008), and indicate that the Brazilian populations of red snapper form a single genetic stock, characterized by intense internal gene flow, contradicting the previous study of Salles et al. (2006), which also used mitochondrial markers, and indicated the existence of two geographically distinct stocks. These authors considered the western stock to be less productive, given the presence of smaller reproductively mature individuals. Unfortunately, this apparent, however unexpected discrepancy between the topologies retrieved by $\mathrm{CytB}$ region and control can not be tested because the sequences CytB cited by Salles et al. (2006) are not available in Genbank. However, as the authors used only 12 specimens and a fragment with only 307 base pairs, we postulate that this discrepancy is due to small sample size and the short DNA fragment.

In addition, our molecular findings contrasts with the morphometric and meristic analyses performed by Sousa-Júnior et al. (2002) and Salles et al. (2006). This discrepancy cannot be easily explained, except by the fact that the two data sets (molecular and morphology) experience different selective forces. However, only a combined analysis, which was not possible in this approach, may be quite clear on this issue.

Regarding the migratory cycle proposed by Ivo and Hanson (1982), our interpretation is that, irrespective of the cohorts number, the juveniles mingle in the breeding area, prior to being recruited to the feeding areas on the continental shelf.

The pattern of marked genetic homogeneity recorded here for $L$. purpureus appears to be typical of western Atlantic lutjanids, such as $L$. campechanus and Rhomboplites aurorubens in the Gulf of Mexico and Florida (Bagley et al. 1999, Garber et al. 2004) and Ocyurus chrysurus in Brazil (Vasconcellos et al. 2008). These species are behaviorally similar, demersal inhabitants of relatively deepwater habitats with rocky bottoms and/or coastal regions close to coral reefs (Allen 1985). They also share pelagic development stages, during which their eggs and larvae are transported by marine currents, which generally limit the potential for speciation. This type of reproductive process results in an extensive intermingling of individuals, which presumably influences the genetic connectivity among populations.

However, other lutjanid species present very different genetic characteristics, with marked divergence among populations. These species include Pristipomoides multidens (Ovenden et al. 2004), Lutjanus erythropterus (Zhang et al. 2006), and L. synagris (Karlsson et al. 2009). Other perciforms, such as the king weakfish, Macrodon ancylodon, also present considerable genetic differentiation at the population level (Santos et al. 2003, 2006). These authors recorded the presence of two distinct genetic stocks of $M$. ancylodon along the Atlantic coast of South America, which they interpreted as the result of a process of allopatric differentiation. One of the determining factors in this case may be differences in water temperature resulting from the action of oceanic 
currents (Santos et al. 2006). Other authors, such as Rocha et al. (2004) have related environmental variables to distribution patterns and differentiation in marine fish species, finding that populations may be connected over thousands of kilometers, where similar habitats exist, as in the case of L. purpureus on the Brazilian coast. It is nevertheless important to bear in mind that, in addition to ecological variables, historical factors and associated evolutionary processes may also contribute to the present-day configuration of geographic ranges in the western Atlantic (Rocha 2003).

\section{Genetic variability and divergence}

The Brazilian populations of red snapper present high levels of genetic variation, considering either haplotype or nucleotide diversity. Unique haplotypes or haplotypes exclusive to a given population predominate. A similar pattern has been observed in other commercially-important lutjanid species, such as L. campechanus (Garber et al. 2004), L. erythropterus (Zhang et al. 2006), and $O$. chrysurus (Vasconcellos et al. 2008). The relative abundance of unique haplotypes - a pattern common to all these species - may mean that many alleles are lost through harvesting, which will eventually affect the genetic diversity of stocks.

It is interesting to note that the highest levels of nucleotide diversity were recorded in the eastern populations (Ceará and Bahia). This may be related to the decline in fishery activities in this region (Ivo and Sousa 1988, Paiva 1997), which would have partially released local populations from this predatory pressure. On the other hand, as the Brazilian population appears to be panmictic, this spatial variation may be related to ecological factors, such as the abundance of coral reefs and oceanic banks off the coast of the Brazilian Northeast. $L$. purpureus, a nektonic demersal species (Szpilman 2000), appears to prefer relatively deep water (30$60 \mathrm{~m}$ ) (Allen 1985) with a rocky or coralline bottom, with juveniles generally inhabiting shallower areas. However, commercial fishing of the species in Brazil is relatively recent - around 50 years (FontelesFilho 1972, Paiva 1997) - which may be a too short period for significant spatial and temporal variations in the diversity of the species to occurred.

Divergence between haplotypes varied from $0.1 \%$ to $6.5 \%$, although in many cases, the value was below $2 \%$, which indicates haplotypes distinguished by a small number of mutations. In other species of the genus, such as L. campechanus, divergence between haplotypes is typically much higher, reaching 9\% (Garber et al. 2004).

\section{Demographic History}

All the populations studied here, with the exception of that from Bahia, presented a smooth unimodal distribution in the plot of pairwise differences, which indicates exponential growth, or population expansion (Frankham et al. 2004). The estimated expansion time of Brazilian $L$. purpureus coincides with the late Pleistocene, as confirmed by Gomes et al. (2008). Pruett et al. (2005) also proposed a Pleistocene expansion for the population of L. campechanus.

The star-shaped haplotype network, and other parameters (SSD, raggedness index) also indicate a process of expansion in the Brazilian red snapper population, which is further confirmed by the $\theta$ intervals, reflecting considerable differences in the size of the population before and after the expansion process. It seems likely that the irregular distribution observed in the plot for Bahia is related primarily to the small size of the sample from this area, given that other analyses indicated expansion in this population, although it may also reflect the relatively ample variance observed in the mismatch distribution.

Garber et al. (2004) recorded a similar pattern in populations of L. campechanus, once again with a single exception (Florida), possibly for reasons similar to those of the L. purpureus population 
from Bahia. Similar results have also been obtained for L. erythropterus (Zhang et al. 2006) and Thallasoma hardwicki (Chen et al. 2004).

Significant negative values of $F s$ and $D$ were recorded for the Brazilian red snapper populations analyzed here, except for $D$ in the Ceará and Bahia populations. These results confirm that the marker used here is non-neutral, and also suggest haplotypes of low frequency distinguished by few mutations, as well as an accumulation of new mutations (Tajima 1989, Fu 1997). The significant negative values of $F S$ also indicate population expansion in the recent past, as observed in other marine fish, such as O. chrysurus (Vasconcellos et al. 2008), L. erythropterus (Zhang et al. 2006), C. acoupa (Rodrigues et al. 2008) and T. hardwicki (Chen et al. 2004).

\section{RED SNAPPERS OF THE WESTERN ATLANTIC: L. PURPUREUS} AND L. CAMPECHANUS

One or Two Species?

Mayr's (1963) biological species concept is based on the idea of the reproductive isolation of populations, and is the most widely-accepted definition of a species, in particular in areas such as population genetics, evolutionary biology, and conservation biology (Frankham et al. 2004). The situation observed in the red snappers $L$. purpureus and L. campechanus is characteristic of that of a single species, considering not only the homogeneity of morphological traits (Allen 1985, Moran 1988, Cervigón 1993, Cervigón et al. 1993, De-la-Rosa 2001, Wilson and Nieland 2001,R.F.C. Souza, unpublished data, Souza et al. 2003), but also the marked similarity in genetic features (Gomes et al. 2008, present study).

However, there is a consensus in the literature that the geographic ranges of these two snappers are not sympatric. Many authors, such as Cervigón (1993) and Allen (1985) believe that these species are parapatric in the western Atlantic, with $L$. campechanus being restricted to the Gulf of Mexico and Atlantic coast of the United States, and absent from the Caribbean (Rivas 1966, Allen 1985), whereas L. purpureus is found south of Cuba, southwards throughout the Caribbean to Bahia in northeastern Brazil (Allen 1985, Cervigón 1993). Some authors (Rivas 1966, Carpenter and Nelson 1971) nevertheless suggest that L. purpureus also occurs in some parts of the coast of the United States, in which case, contact between populations, and gene flow, would be possible. Either way, the restricted ranges of the two species contrasts considerably with those of other western Atlantic snappers, such $L$. vivanus, $L$. synagris and $L$. buccanella, which present a continuous distribution along the eastern seaboard of the New World (Allen 1985, Cervigón 1993).

The analysis presented here demonstrated that L. campechanus and L. purpureus share mitochondrial haplotypes, indicating the occurrence of gene flow between their populations. The AMOVA also found that the majority of the variance was within rather than among populations or geographic groups, even though the Fst values for pairwise comparisons between species were significant. The magnitude of the recorded values $\left(F / \Phi_{\mathrm{ST}}=0.236, P<0.01\right)$ indicates only moderate genetic differentiation between the two snapper species, and may simply reflect the elevated polymorphism of the control region in these fish. Similar values were recorded in intra-population comparisons in lutjanids, including species from the western Atlantic (Ovenden et al. 2004, Vasconcellos et al. 2008).

Other aspects of the results also support the hypothesis that only a single species of red snapper exists in the western Atlantic, such as the star-shaped haplotype network and the absence of phylogeographic structuring in the phylogenetic tree, which clearly indicates the existence of a single monophyletic group of red snappers, a 
strong evidence for the existence of a single species (Cracraft 1983). A similar conclusion was obtained in the preliminary analysis of Gomes et al. (2008).

The sum of the evidences appears to indicate that L. campechanus and L. purpureus actually represent a single species of red snapper with moderately restricted gene flow. The two species clearly share a common evolutionary history, but given the nature of the marker used here (haploid, with strictly maternal inheritance) (Brown 2008), it may be necessary to consider alternatives explanations for the observed scenario.

One possibility is that the gene flow detected between populations reflects the incomplete separation of lineages, with the retention of an ancestral polymorphism. This would explain the absence of reciprocal monophyly between the two species, and may indicate that the cladogenetic event which rose the two species was relatively recent, given the fact they still share the same mitochondrial lineage. A second alternative is the possibility of hybridization or introgression, resulting from the generation of a fertile hybrid, which subsequently breeds with members of one or both of the original species, resulting in gene flow between them. Such events were well documented (Freyhof et al. 2005, Sanz et al. 2006, Castillo et al. 2008). This process would nevertheless depend on the presence of a contact zone between the ranges of the two species, which has yet to be confirmed in the present case. Hybridization was recorded in a number of lutjanid species, such as L. synagris and O. chrysurus (Domeier and Clarke 1992, Loftus 1992). Recent analyses (Rocha and Molina 2008, Nirchio et al. 2008, 2009) have confirmed that the chromosomic constitution of the lutjanids, including species of the genera Lutjanus, Ocyurus, and Rhomboplites, is highly conserved, which would permit introgressive hybridization or hybridization. At the moment, however, there is no evidence of such hybridization in the red snappers. Confirmation of any of these alternatives would require a more reliable evaluation of gene flow based on the analysis of additional mitochondrial loci and nuclear genes.

The absence of genetic sub-structuring among populations of marine fish was recorded in a wide range of western Atlantic fish species, including other lutjanids (Garber et al. 2004, Santa Brígida et al. 2007). One of the possible explanations for this phenomenon is the considerable dispersal potential of the pelagic larval forms, which can be transported over long distances by ocean currents. The dimensions and relative continuity of the marine environment in this region may be an additional factor.

\section{Patterns of Genetic Variation and Demographic}

The populations of red snappers analyzed in the present study presented high levels of genetic polymorphism. The overall pattern of variation was similar in the two species, although diversity was greater in the Brazilian L. purpureus. The species could not be differentiated based on indices of genetic variability. In addition, many parameters of interspecific genetic distance were lower than those recorded within populations of both species (Garber et al. 2004, Gomes et al. 2008, present study) and also other lutjanids (Ovenden et al. 2004).

Despite not analyzing the hypervariable portion of the control region, Gomes et al. (2008) recorded a similar pattern in these species. Grant and Bowen (1998) have argued that elevated haplotype and nucleotide diversity may be evidence of a stable population with a long evolutionary history.

As both red snappers are gonochoric and oviparous, and lack sexual dimorphism (Dela-Rosa 2001, R.F.C. Souza, unpublished data, Souza et al. 2003), we conclude that cohorts of both species have distinct breeding areas, with the intense intermingling of individuals occurring after fertilization, during the initial stages of development, a process facilitated by ocean currents. Considering a single species of western Atlantic red snapper, as suggested by the molecular 
data, it would seem likely that an extensive area of intermingling exists, which would be responsible for the elevated levels of genetic polymorphism and the similarities in the patterns of variation observed in the populations analyzed here.

When the two red snappers were combined for analysis, the plot of the pairwise differences between haplotypes revealed a unimodal distribution, characteristic of a population that has undergone expansion in the past (Slatkin and Hudson 1991, Rogers and Harpending 1992), as observed by Gomes et al. (2008). This conclusion is also supported by other parameters, such as the low and non-significant SSD and raggedness index, and the significantly negative value of Fs. The same pattern was found in both species individually (Garber et al. 2004, present study), and in other lutjanids, such as L. erythropterus (Zhang et al. 2006). The estimated expansion time of L. campechanus coincides with the late Pleistocene, as reported by Pruett et al. (2005).

\section{IMPLICATIONS FOR THE CONSERVATION OF THE SPECIES}

Reliable data on geographic range and genetic variability are crucial to the development of successful conservation and management strategies for any species, but especially those which suffer intense anthropogenic impacts, as in the case of the red snapper. Information derived from the analysis of DNA fragments has been increasingly employed in conservation programs. In the specific case of the fish icthyofauna, a large number of studies have confirmed the effectiveness of the mitochondrial control region for the detection of gene flow between populations or species, and the understanding of genetic variation, phylogeographic patterns, and demographic history (Garber et al. 2004, Sanz et al. 2006, Zhang et al. 2006, Gomes et al. 2008, Rodrigues et al. 2008, Vasconcellos et al. 2008).

In the present study, the analysis of the control region of populations of Brazilian L. purpureus revealed the existence of a single genetic stock, which is an extremely important finding for the management of fishery stocks. In addition, high levels of genetic variation and a predominance of unique and exclusive haplotypes were found. This pattern of haplotype distribution may reflect an imbalance of the species genetic diversity, which could require the implementation of effective management strategies that integrate the molecular data with those on ecological variables and reproductive parameters.

Together with data from previous analyses (Gomes et al. 2008), the results of the present study indicate emphatically that $L$. purpureus and $L$. campechanus represent different populations of the same species, with an ample geographic distribution stretching from the southeastern United States to northeastern Brazil. However, as the genetic marker used here represents a single locus with maternal inheritance, we cannot rule out other possible explanations for the observed gene flow between species, such as introgression, hybridization or the retention of an ancestral polymorphism.

While the results of the molecular analysis presented here indicate the existence of a single, genetically diverse species, a more reliable evaluation would include nuclear genes. Irrespective of their taxonomic status, if each species represents a panmictic population within its own geographic range, as suggested here and in previous studies (Gold et al. 2001, Garber et al. 2004, Gomes et al. 2008), their management as separate stocks may be the most effective approach over the long term. Such management is already in place for L. campechanus, but in the case of L. purpureus, there is an urgent need for the implementation of measures that will guarantee the maintenance of the genetic diversity of the species, and impede the loss of alleles.

\section{ACKNOWLEDGMENTS}

This study was supported by Conselho Nacional de Desenvolvimento Científico e Tecnológico (CNPq), grants n 308477/2006-5 and 477542/2006-9. 


\section{RESUMO}

Para o presente estudo utilizou-se a região controle mitocondrial para investigar os padrões filogeográficos e a estrutura populacional de Lutjanus purpureus $e$ para avaliar a similaridade genética entre $L$. purpureus e L. campechanus. Para a análise inicial foram obtidas sequências de 810 pares de bases (pb) da região controle para 239 espécimes de L. purpureus de quatro localidades da costa brasileira. Os resultados mostraram a presença de uma população panmítica caracterizada por altos valores de diversidade genética. Utilizou-se um segmento de 299 pb da porção hipervariável para comparar L. purpureus e L. campechanus. Dos 414 indivíduos analisados foram identificados 275 haplótipos. A árvore filogenética e a rede de haplótipos não mostraram subestruturação filogeográfica entre as duas espécies, com intensa mistura de indivíduos. Considerando a grande similaridade morfológica, os dados moleculares apresentados, aqui indicam que apenas uma única espécie de pargo vermelho existe ao longo do atlântico ocidental.

Palavras-chave: região controle, Lutjanus purpureus.

\section{REFERENCES}

ALLEN GR. 1985. FAO species catalogue. Snappers of the world. Vol. 6 Food and Agriculture Organization of the United Nations, Rome 6: 208.

ARIS-BROSOU S AND EXCOFFIER L. 1996. The impact of population expansion and mutation rate heterogeneity on DNA sequence polymorphism. Mol Bio Evol 13: 494-504.

Bagley MJ, Lindquist DG AND Geller JB. 1999. Microsatellite variation, effective population size, and population genetic structure of vermilion snapper, Rhomboplites aurorubens, off the southeastern USA. Mar Biol 134: 609-620.

BANDELT HJ, FORSTER P AND ROHL A. 1999. Median-joining networks for inferring intraspecific phylogenies. Mol Bio Evol 16: 37-48.

BROWN JR, BECKENBACH AT AND SMITH MJ. 1993. Intraespecific DNA sequence variation of the mitochondrial control region of white sturgeon (Acipenser trasnmontanus). Mol Bio Evol 10: 326-341.

BROWN KH. 2008. Fish mitochondrial genomics: sequence, inheritance and functional variation. J Fish Biol 72: 355-374.

CARPENTER JS AND NELSON WR. 1971. Fishery potential for snapper and grouper in the Caribbean area and the Guianas. FAO Fish Rep Rome 7(1/2): 21-26.
CAstillo AGF, A YLlon F, MORAn P, IZQUiERdo JI, MARTINEZ JL, BEALl E AND GARCIA-VAZQUEZ E. 2008. Interspecific hybridization and introgression are associated with stock transfers in salmonids. Aquaculture 278: 31-36.

CERVIGÓN F. 1993. Los peces marinhos de Venezuela. $2^{\mathrm{a}}$ edição, Vol. II. Caracas, Venezuela, Fundacion Científica Los Roques, $498 \mathrm{p}$.

Cervigón F, CAPriani F, Fischer W, Garibaldi L, HendrickX M, Lemus AJ, Márquez R, Poutiers JM, RoBAINA G AND RodRIGUEZ B. 1993. FAO species identification sheets for fishery purpose. Field Guide to the Commercial marine and Brackish-water Resources of the Northerrn Coast of South America. Rome FAO, 513 p.

Chen CA, Ablan MCA, MCManus JW, Bell JD, TuAn VS, CABAnban AS AND SHAO KT. 2004. Population Structure and Genetic Variability of Six Bar Wrasse (Thallasoma hardwichi) in Northern South China Sea revealed by Mitochondrial Control Region sequences. Mar Biotechnol 6: 312-326.

CRACRAFT J. 1983. Species concepts and speciation analysis. Curr Ornithol 1: 159-187.

De-La-Rosa G, Elena M And RÉ-Regis C. 2001. Aspectos de la reproducción de Lutjanus Campechanus en Campeche, México. Cienc Pesq 14: 141-146.

DOMEIER ML AND CLARKE ME. 1992. A laboratory produced hybrid between Lutjanus synagris and Ocyurus chrysurus and a probable hybrid between $L$. griseus and $O$. chrysurus (Perciformes: Lutjanidae). B Mar Sci 50(3): 501-507.

EXCOFFIER L, LAVAL GAND SCHNEIDER S. 2005. Arlequin v. 3.0: An integrated software package for population genetics data analysis. Evol Bioinform Online 1: 47-50.

EXCOFFIER L, SMOUSE PE AND QuATTRO JM. 1992. Analysis of molecular variance inferred from metric distances among DNA haplotypes: application to human mitochondrial DNA restriction data. Genetics 131: 479-491.

FONTELES-FILHO AA. 1972. Importância do pargo como recurso pesqueiro do Nordeste brasileiro. Equipesca Jornal 43: 8 .

FrankHAm R, BALlou JD AND BRISCOE DA. 2004. A Primer of Conservation Genetics. Cambridge: Syndicate of University Press Cambridge, UK, 280 p.

Freyhof J, Lieckfeldt D, Pitra C ANd Ludwig A. 2005. Molecules and morphology: Evidence for introgression of mitochondrial DNA in Dalmatian cyprinids. Mol Phylogenet Evol 37: 347-354.

FU YX. 1997. Statistical methods of neutrality of mutations against population growth, kitchhiking and background selection. Genetics 147: 915-925.

Garber AF, Tringali MD AND STUCK KC. 2004. Population structure and Variation in Red snapper (Lutjanus campechanus) from the Gulf of Mexico and Atlantic Coast of Florida as determined from mitochondrial DNA control region sequence. Mar Biotechnol 6: 175-185.

GOLD JR, PAK E AND RICHARDSON L. 2001. Microsatellite variation among red snapper (Lutjanus campechanus) from the Gulf of Mexico. Mar Biotechnol 3: 293-304. 
Gomes G, Santos S, Vallinoto M, Schneider H, Orti G AND SAMPAIO I. 2008. Can Lutjanus purpureus (South red snapper) be "legally" considered a red snapper (Lutjanus campechanus)?. Genet Mol Biol 31(Suppl. 1): 372-376.

GRANT WS AND BOWEN BW. 1998. Shallow population histories in deep evolutionary lineages of marine fishes: Insights from sardines and anchovies and lessons for conservation. J Hered 89: 415-426.

HALL TA. 1999. BioEdit: a user-friendly biological sequence alignment editor and analysis program for Windows 95/98/NT. Nucl Acid S 41: 95-98.

HARPENDING HC. 1994. Signature of ancient population growth in a low-resolution mitochondrial DNA mismatch distribution. Hum Biol 66: 591-600.

Ivo CTC AND Hanson AJ. 1982. Aspectos da Biologia e Dinâmica Populacional do Pargo, Lutjanus purpureus Poey, no Norte e Nordeste do Brasil. Arq Ciênc do Mar 22(1/2): 1-41.

Ivo CTC AND SousA MJB. 1988. Sinopse de informações sobre o pargo, Lutjanus purpureus Poey (Pisces: Lutjanidae), no norte e nordeste do Brasil. Arq Ciênc do Mar 27: 57-67.

IWATSUKI Y, AKAZAKI M AND YOSHINO T. 1993. Validity of a Lutjanid fish, Lutjanus ophuysenii (Bleeker) with a related species, L. vitta (Quoy et Gaimard). Jpn J Ichthyol 40(1): 47-59.

Karlsson S, Saillant E AND GOLD JR. 2009. Population Structure and Genetic Variation of Lane Snapper (Lutjanus synagris) in the Northern Gulf of Mexico. Mar Biol 156: 1841-1855.

Lee W, Coroy J, Howell WH AND KoOcher TD. 1995. Structure and evolution of teleost mitochondrial control regions. J Mol Evol 41: 54-66.

LiBRADO P AND RozAS J. 2009. DnaSP v5: a software for comprehensive analysis of DNA polymorphism data. Bioinformatics 25: 1451-1452.

LofTUS WF. 1992. Lutjanus ambiguous (Poey), a natural intergenic hybrid of Ocyurus chrysurus and Lutjanus synagris (Linnaeus). B Mar Sci 50: 489-500.

MAYR E. 1963. Animal Species and Evolution. Harvard University Press, Cambridge, MA, 797 p.

MORAN D. 1988. Species profiles: life histories and environmental requirements of coastal fishes and invertebrates (Gulf of Mexico): red snapper. U.S. Fish and Wildlife Service. Biological Report 82(11.83) 19 p. U. S. Army Corps of Engineers, TR EL-82-4.

Moura RL AND Lindeman KC. 2007. A new species of snapper (Perciformes: Lujanidae) from Brazil, with comments on the distribution of Lutjanus griseus and $L$. apodus. Zootaxa 1422: 31-43.

NEI M. 1987. Molecular Evolutionary Genetics. New York: Columbia Univ. Press, NY, USA, 512 p.

NELSON JS. 2006. Fishes of the World. $4^{\text {th }}$ ed., J Wiley \& Sons, Inc. New Jersey, 539 p.
NirChio M, Oliveira C, FERreira DC, RONDON R, PÉreZ JE, HetT AK, Rossi AR AND Sola L. 2009. Cytogenetic characterization of Rhomboplites aurorubens and Ocyurus chrysurus, two monotypic genera of Lutjaninae from Cubagua Island, Venezuela, with a review of the cytogenetics of Lutjanidae (Teleostei: Perciformes). Neotrop Ichthyol 7(4): 587-594.

Nirchio M, Rondón R, OliveIra C, FERreira IA, Martins C, Pérez J, Sola L and Rossi AR. 2008. Cytogenetic studies in three species of Lutjanus (Perciformes: Lutjanidae: Lutjaninae) from the Isla Margarita, Venezuela. Neotrop Ichthyol 6(1): 101-108.

OVEnden JR, SALini J, O’CONNOR S AND StReEt R. 2004. Pronounced genetic population structure in a potentially vagile fish species (Pristipomoides multidens, Teleostei; Perciformes; Lutjanidae) from the East Indies triangle. Mol Ecol 13: 1991-1999.

PAIVA MP. 1997. Recursos Pesqueiros Estuarinos e Marinhos do Brasil. Fortaleza, UFC Edições, Fortaleza, 278 p.

PAlstra FP, O'CONNELl MF AND RuZZANTE DE. 2007. Population structure and gene flow reversals in Atlantic salmon (Salmo salar) over contemporary and long-term temporal scales: effects of population size and life history. Mol Ecol 16: 4504-4522.

Pruett CL, Saillant E AND Gold JR. 2005. Historical Population Demography of Red Snapper (Lutjanus campechanus) from the Northern Gulf of Mexico Based on Analysis of Sequences of Mitochondrial DNA. Mar Biol 147: 593-602.

RIVAS LR. 1966. Review of the Lutjanus campechanus complex of red snappers. Q. J Flor Acad Sci 29(2): 117-136.

RochA EC AND MoLINA WF. 2008. Cytogenetic analysis in western Atlantic snappers (Perciformes, Lutjanidae). Genet Mol Biol 31/2: 461-467.

RocHA LA. 2003. Patterns of distribution and processes of speciation in Brazilian reef fishes. J Biogeogr 30: 1161-1171.

ROCHA LA, ROBERTSON DR, ROMAN J AND BOWEN BW. 2004. Ecological speciation in tropical reef fishes. P Roy Soc, p. 1-7.

Rodrigues R, SchNeIder H, SANTOS S, VALlinOto M, SAINPAUl U AND SAMPAIO I. 2008. Low levels of genetic diversity depicted from mitochondrial DNA sequences in a heavily exploited marine fish (Cynoscion acoupa, Sciaenidae) from the Northern coast of Brazil. Genet Mol Biol 31/2: 487-492.

Rogers AR AND HARPENDING HC. 1992. Population growth makes waves in the distribution of pairwise genetic differences. Mol Biol Evol 9: 552-569.

SAllEs R, FonTElEs-FilHo AA, FURTADO-NETO MAA, CARR SM AND FREITAS SM. 2006. Morphometric and mitochondrial DNA analyses of the Caribbean red snapper, Lutjanus purpureus (Teleostei, Lutjanidae), in western Atlantic off Northern Brazil. Bol Inst Pesca 32/2: 115-125.

SAMBROOK J AND RUSSELL D. 2001. Molecular Cloning: A Laboratory Manual. Cold 303 Spring Harbor Laboratory press. Cold Spring Harbor New York. 
SANGER F, NiCHLEN S AND COULSON AR. 1977. DNA Sequencing with Chain-Termination Inhibitors. Proceeding of the National Academy of Science of the USA 74: 5463-5468.

SAnta Brígida EL, Cunha DB, Rego PS, SAmpaio I, SCHNEIDER H AND VALLINOTO M. 2007. Population analysis of Scomberomorus cavalla (Cuvier, 1829) (Perciformes, Scombridae) from the Northern and Northeastern coast of Brazil. Braz J Biol 67(Suppl. 4): 919-924.

SANTOS S, Hrbek T, FARIAS IP, SchNeIDER H AND SAMPaio I. 2006. Population genetic structuring of the king weakfish, Macrodon ancylodon (Sciaenidae), in Atlantic coastal waters of South America: deep genetic divergence without morphological change. Mol Ecol 15: 4361-4373.

SAntos S, SchneIder H AND SAmpaio I. 2003. Genetic differentiation of Macrodon ancylodon (Sciaenidae, Perciformes) populations in Atlantic coastal waters of South America as revealed by mtDNA analysis. Genet Mol Biol 26: 151-161.

Sanz N, Cortey M, Pla C and García-Marín JL. 2006. Hatchery introgression blurs ancient hydridization between brown trout (Salmo trutta) lineages as indicated by complementary allozymes and mtDNA markers. Biol Conserv 30: 278-289.

SCHNEIDER S AND EXCOFFIER L. 1999. Estimation of past demographic parameters from the distribution of pairwise differences when the mutation rates vary among sites: application to human mitochondrial DNA. Genetics 152: 1079-1089.

Silva-OliveIra GC, REgo PS, SchNeIdER H, SAMPAio I AND VALLINOTO M. 2008. Genetic characterisation of populations of the critically endangered Goliath grouper (Epinephelus itajara, Serranidae) from the Northern Brazilian coast through analyses of mtDNA. Genet Mol Biol 31/4: 988-994.

SLATKIN M AND HUDSON RR. 1991. Pairwise comparisons of mitochondrial DNA sequences in stable and exponentially growing populations. Genetics 129: 555-562.
SOUSA-JÚNIOR JP, VIANA MSR AND SAKER-SAMPAIO S. 2002. Diversificação intra-específica do pargo, Lutjanus purpureus Poey, no Norte e Nordeste do Brasil. I caracteres morfométricos. Acta Sci 24(4): 973-980.

SouzA RFC, Ivo CTC AND SouzA RAL. 2003. Aspectos da Reprodução do pargo, Lutjanus purpureus POEY, 1875 na costa Norte do Brasil. Bol Téc Cient CEPNOR 3(1): 107-121.

SzPILMan M. 2000. Peixes Marinhos do Brasil: Guia Prático de Identificação. Rio de Janeiro, 288 p.

TAJIMA F. 1989. Statistical method for testing the neutral mutation hypothesis by DNA polymorphism. Genetics 123: 585595.

TAMURA K, Dudley J, NeI M AND Kumar S. 2007. MEGA4: Molecular Evolutionary Genetics Analysis (MEGA) software version 4.0. Mol Biol Evol 24(8): 1596-1599.

THOMPson JD, GiBson TJ, PLEWNiAK F, JEANMOUGIN F AND HIGGINS DG. 1997. The CLUSTALX windows interface: flexible strategies for multiple sequence alignment aided by quality analysis tools. Nucleic Acids Res 24: 4876-4882.

VAsconcellos A, Viana P, Paiva PC, Schama R AND SOLE-CAVA A. 2008. Genetic and morphometric differences between yellowtail snapper (Ocyurus chrysurus, Lutjanidae) populations of the tropical West Atlantic. Genet Mol Biol 31(Suppl. 1): 308-316.

WeIR BS AND HiLl WG. 2002. Estimating F-statistics. Annu Rev Genet 36: 721-750.

Wilson CA AND NiELAND DL. 2001. Age and growth of red snapper, Lutjanus campechanus, from the northern Gulf of Mexico off Louisiana. Fish Bull 99(4): 653-664.

XIA X AND XIE Z. 2001. DAMBE: data analysis in molecularbi ology and evolution. J Hered 92: 371-373.

Zhang J, CAI Z AND HuAng L. 2006. Population genetic structure of crimson snapper Lutjanus erythropterus in East Asia, revealed by analysis of the mitochondrial control region. J Mar Sci 63: 693-704. 